\title{
AOR
}

Selected Papers of \#AoIR2020: The $21^{\text {st }}$ Annual Conference of the Association of Internet Researchers Virtual Event / 27-31 October 2020

\section{NEUROTIC INFLUENCER - FEELING RULES AND THE AFFECTIVE PRACTICE OF ANXIETY IN SOCIAL MEDIA INFLUENCER WORK}

\author{
Mari Lehto \\ University of Turku
}

In 2019 Finnish PR-agency published a survey reporting that almost one of three Finnish social media influencers have considered quitting. The research revealed that the stressful nature of the social media environment and the constant race to publish high-quality content is experienced as highly exhausting. (Manifesto, 2019.) Meanwhile, numerous Finnish influencers are participating in social media campaigns encouraging people to speak openly about fatigue, depression and anxiety, and mental health is commercialized in social media with new vigor. This small-scale, interpretative study discusses the phenomenon by exploring the intimate cultures of Finnish social media influencers who also share family-related content. Through in-depth qualitative interviews with four Finnish influencers and online observation of their social media accounts, the paper investigates how influencers negotiate the feeling rules (Hochschild, 2003 [1983]) that govern (maternal) femininity on social media. My data do not allow for the possibility of generalization but are rich, nuanced, and offer insight into one method of investigating the ambivalent lived experiences and emotional pressures of 'do what you love and love what you do' ethic (e.g. Duffy 2016) where emotional investment in one's work encompasses all areas of life.

The four influencers interviewed for this study tell about their lives "as lived" as the central theme of their output (Abidin 2015) but the content they share is simultaneously carefully curated. Influencers' popularity depends on protecting the connection with their followers and they police themselves closely to adapt to followers' expectations (eg. Abidin 2013; Mäkinen 2018). Applying social psychologist Margaret Wetherell's (2012, 2014) concept of "affective practice" and Akane Kanai's (2019, 2019b) implementation of Arlie Hochschild's work in the context of digital media, I ask how feeling rules shape the ways in which Finnish influencers work to produce selves that are agreeable to their followers and cope with the emotional weight of precarious social media work. The paper argues for using the affective practice of anxiety as a theoretical concept to explore the influencers' routinized emotional behaviour in their attempts to decrease the

Suggested Citation (APA): Lehto, M. (2020, October). Neurotic Influencer - Feeling Rules And The Affective Practice Of Anxiety In Social Media Influencer Work. Paper presented at AoIR 2020: The 21th Annual Conference of the Association of Internet Researchers. Virtual Event: AolR. Retrieved from http://spir.aoir.org. 
discrepancy between their emotions and cultural expectations. The notion of affective practice is useful when contemplating what affects such as anxiety do (Loveday, 2016: 1148; Ahmed, 2004: 4). The experience of anxiety is viscerally felt at the individual level, but it is important to consider the role of anxiety and insecurity on more a structural level as well. As Gill and Pratt (2008) point out, this is highly relevant in fields of work in which individuals are judged on what they produce.

The four influencers discuss at length about their negotiations about anxieties and uncertainties within their construction of relatable influencer identity. They all acknowledge the power of performative vulnerability (see Koivunen, Kyrölä \& Ryberg 2018) and emphasize that only sharing positive sentiments is often regarded as superficial. The paper suggests that although anxiety can be considered a negative side effect of stressful social media work, sharing it on social media can also be understood as a tactic that plays a central role in the lifestyle influencer industry. Drawing on Vik Loveday's (2018) analysis of the "neurotic academic", I suggest that the construction of an entrepreneurial influencer self is underpinned by anxiety. In her study of academic staff working on fixed-term contracts, Loveday (2018) notes that anxiety can be conceptualized as a kind of tactic of "neuroliberal governance" (Isin, 2004): "It is both produced and productive, it is both an effect and affective" (Loveday 2018, p.163). Applying Loveday's (2018, p.162) insights, I consider the "neurotic influencer" to be an entrepreneurial figure that is governed through anxiety while being expected to take responsibility for the self-management of this anxiety. From this point of view, opening up about the affective practices of anxiety can be interpreted as a tactic through which the influencers perform feelings by either following the feeling rules or challenging but also capitalizing on them. In other words, the neurotic influencer as a figure governs itself through responses to anxieties, not in spite of them (see Loveday, 2018, p. 161).

The neurotic influencer is a figure of this neoliberal media culture. The performances of anxiety offer evidence of its claims to authenticity; however, at the same time, this entrepreneurial figure is expected to self-manage the structural anxieties that are outside of its control. The ambivalent influencer culture fosters sentimental discourse that, in keeping with Berlant (2008, p.1-2), criticizes structures and "bad ideologies" about women's suffering while at the same time retaining faith in many of the promises that originally caused the suffering. Anxiety pushes the influencers to exceed themselves in their work all the while creating relatable social media subjects.

\section{References}

Abidin, C. (2013). Cyber-BFFs: Assessing women's 'perceived interconnectedness' in Singapore's commercial lifestyle blog industry. Global Media Journal Australian Edition 7(1).

Abidin, C. (2015). "Communicative Intimacies: Influencers and Perceived Interconnectedness." Ada: A Journal of Gender, New Media, \& Technology 8. DOI: $10.7264 / \mathrm{N} 3 M W 2 F F G$ 
Adams, V., Murphy, M., and Clarke, A.E. (2009). Anticipation: technoscience, life, affect, temporality. Subjectivity, 28, 246-265.

Ahmed S. (2004). The Cultural Politics of Emotion. London: Routledge.

Berlant, L. (2008). The Female Complaint. The Unfinished Business of Sentimentality in American Culture. Durham: Duke University Press.

Duffy, B. E. (2016). The romance of work: Gender and aspirational labour in the digital culture industries. International Journal of Cultural Studies, 19(4), 441-457.

Gill, R. and Pratt, A.C. (2008). In the social factory? Immaterial labour, precariousness and cultural work. Theory, Culture \& Society, 25(7-8), 1-30. doi:

$10.1177 / 0263276408097794$

Hochschild, A. R. (1983). The managed heart: commercialization of human feeling. Berkeley: University of California Press.

Kanai A. (2019a). Gender and Relatability in Digital Culture: Managing Affect, Intimacy and Value. Cham Switzerland: Palgrave Macmillan.

Kanai A. (2019b). On not taking the self seriously: Resilience, relatability and humour in young women's Tumblr blogs. European Journal of Cultural Studies 22(1): 60-77.

Koivunen, A-R., Kyrölä, K., \& Ryberg, I. (2018). Vulnerability as a political language. In K. Kyrölä, I. Ryberg (eds.), The Power of Vulnerability: Mobilizing Affect in Feminist, Queer and Anti-racist Media Cultures. Manchester: Manchester University Press.

Loveday V. (2016). Embodying deficiency through "affective practice": Shame, relationality, and the lived experience of social class and gender in higher education. Sociology 50(6): 1140-1155.

Loveday, V. 2018. The neurotic academic: anxiety, casualisation, and governance in the neoliberalising university. Journal of Cultural Economy. 11(2), 154-166.

Manifesto. (2019). 'Somevaikuttaja 2019 -barometri'. Viestintätoimisto Manifesto, 3 September. https://www.dropbox.com/s/0o5amosog9p5vmc/Somevaikuttajabarometri2019.pdf?dl=0 
Mäkinen, K. (2018). Negotiating the Intimate and the Professional in Mom Blogging. In: S. Taylor, S. Luckman (eds.), The New Normal of Working Lives Critical Studies in Contemporary Work and Employment. Palgrave Macmillan. 129-146.

Wetherell M. (2012). Affect and Emotion: A New Social Science Understanding. London: Sage Publications.

Wetherell M. (2014). Feeling rules, atmospheres and affective practice: Some reflections on the analysis of emotional episodes. In: Maxwell $\mathrm{C}$ and Aggleton $\mathrm{P}$ (eds.) Privilege, Agency and Affect. Basingstoke: Palgrave Macmillan, pp. 221-239. 